podia all contain a large number of very similar species and doubt still exists as to the status of certain species in the last two genera named. Eurema hecabe and Amathusia phidippus, the two most widely distributed members of their respective genera, both exhibit marked individual variation, the geographical races are not readily separable, the sexes occur in approximately equal numbers and both so closely resemble certain allied congeneric species that determination is frequently a matter of doubt and difficulty. On the other hand, species such as Papilio brookiana, Pareronia valeria and Ideopsis daos, in which the females are strikingly rare, have well-defined geographical races but exhibit little or no individual variation and have no close allies. Such instances can be multiplied.

Application of the views expressed here to mimicry amongst Malaysian butterflies is of great interest. The models of the 'true' mimetic butterflies of the Malay Peninsula are members of the Aristolochia group of the genus Papilio, the genus Delias or the family Danaidæ, and the larvæ of these are known to feed on plants containing toxic substances. As a rule, the mimetic butterflies are rare but, in cases where their habits are sufficiently known, they are found to have the characteristics of old species, having no close allies, a low sex ratio and exhibiting little individual but marked subspecific variation. This state of affairs suggests that the mimetic forms have ancient wing patterns which have been preserved through the agency of natural selection owing to the advantages associated therewith.

The equable conditions of life prevailing in the tropics, which must be of considerable assistance to new species during their early struggles for existence, and the large number of broods produced annually, indicate that it is in equatorial regions that most new species have been produced.

It is hoped that, at a subsequent date, it will be possible to discuss the evidence which supports these arguments in greater detail than is permissible here.

"Elm Lodge", Elm Road, A. Streven Corbet.

Earley, Reading. Nov. 1 .

\footnotetext{
${ }^{1}$ Corbet, A. S., Rubber Research Institute of Malaya Journal, 3, 16 ; 1931.

${ }^{2}$ Winslow, C. E. A., "Newer Knowledge of Bacteriology and Immunology", (Univ. Chicago Press), p. 56, 1928.

${ }^{3}$ Ford, H. D., and Ford, E. B., Transactions of the Entomological Society of London, 78,$345 ; 1930$.
}

\section{Glycogen in Cartilage}

WE were much interested in the letter from Prof. H. A. Harris in Nature of December 31, p. 996, in which he directs attention to the presence of glycogen in hypertrophic cartilage cells and correlates this with a secretion of phosphatase by these cells.

We feel, however, that it should be made clear that phosphatase is also actively secreted by the osteoblasts"1, 2. According to Prof. Harris, "osteoblasts and highly vascularised bone contain no glycogen". These facts are not necessarily inconsistent with the suggestion that he has put forward.

Prof. Harris in his letter refers to the hypertrophic cartilage as "senescent". Although hypertrophic cartilage, being a transitory structure, may eventually become senescent (degenerative), the process of chondroblastic hypertrophy is not in itself a degenerative change but a specific differentiation. One of us
(H.F.) formerly held the contrary view, but was forced to a change of opinion on finding that undifferentiated cartilage rudiments, when isolated and cultivated in vitro under standardised environmental conditions, only developed areas of hypertrophic cartilage if destined to do so in normal development, and only in that part of the rudiment where hypertrophy would normally have appeared ${ }^{2,3}$. Degeneration may occur in small-celled cartilage in vitro, but in such tissue we have never found any histological appearance at all suggestive of the chondroblastic hypertrophy characteristic of an ossification centre. Moreover, the secretion of phosphatase in cultures of either hypertrophic cartilage or of osteoblasts is always correlated with a healthy condition and not with regression, as indicated by the fact that in unhealthy, though surviving cultures, one of the first cellular activities to disappear is the production of phosphatase.

H. B. FELL.

Strangeways Research Laboratory, Cambridge.

Lister Institute, London.

1 Martland and Robison, Biochem. J., 18, 1354; 1924

2 Fell and Robisnn, Biochem. J., 24, $1905 ; 1930$

3 Niven, J. Path. and Bact., 34, 307; 1931 .

\section{A Peculiar Visual Experience}

IN NATuRE of December 10 (p. 888) Dr. K. Mackenzie describes visual sensations consequent on the sudden subjection of his eyes to a brilliant flash. A similar experience of my own may therefore be worthy of record.

At the end of June, 1922, I was bicycling from King's Lynn to Leicester. It was a fine morning and the sun was of course behind me, when a motor-car, meeting me suddenly, unexpectedly flashed the sun from its wind-screen straight into my eyes. Shortly afterwards I seemed to see splashes of blood on the road. My sight was a bit troubled, but as the appearance was pronounced and persistent I dismounted to examine the road, and found that the red was in my eyes. Riding on I noticed that the red splashes had changed to green, which after a time died away.

I cannot estimate the duration precisely, but it was considerably longer than the ninety seconds noted by Dr. Mackenzie. The circumstances were not conducive to precise observation. The importance of the experience to me is that occasionally during the following years I have noticed brief repetitions of the appearance, generally taking the form of an irregular but defined blotch, and ending in white with a purplish border. It was apparently only the right eye that was affected, at least permanently, and about two years ago it became obviously difficult to read with it. It seemed that there was a lesion of the retina over the central area and this was confirmed by an oculist. The affection is most noticeable when rising in the morning or when looking from relative darkness into a bright light.

It is true that my eyes, especially the right one, have been subjected to fairly severe use throughout fifty years, but it is to this particular experience that I refer the damage, and I would suggest to Dr. Mackenzie that he should for the present rest his eyes as much as possible and consult an oculist without delay.

F. A. Bather.

46, Marryat Road,

London, S.W.19.

Dec. 14. 